\title{
Plans Launched for Establishing MRS Washington, DC Office
}

Several Materials Research Society volunteers from the Washington, DC area met on the morning of January 24 to discuss implementing an MRS Office of Public Affairs. This site inspection and planning meeting was held at the new MRS office's location in the American Geophysical Union Building at 2000 Florida Avenue NW, Washington, DC 20009. It occupies space in the American Institute of Physics complex where the AIP Government Liaison, Physics Today, and Education Division offices are also located.

The meeting began the process of implementing a motion proposed to MRS Council by the External Affairs Committee to establish a Washington presence for the
Society. The motion was approved at the 1989 MRS Fall Meeting last December in Boston. The office will enable more effective communications between the Society and congressional offices, federal agencies and other private Washington-based technical organizations concerned with materials research activities, legislation and policies.

"We look forward to better facilitating a flow of information to members about key activities that influence the future and fortunes of materials science and engineering," said Elton N. Kaufmann, chairman of the Subcommittee on Public Affairs of the MRS External Affairs Committee. "As we have often been advised, being close to the hub of such activities is indispensable to rapid and responsive reporting on developments. We will primarily use the pages of the MRS Bulletin to inform the membership," continued Kaufmann, who is also chairman of the Editorial Boards for the MRS Bulletin.

For further information on the new MRS Office of Public Affairs, contact the Coordinator of the Implementation Task Group, Graham K. Hubler, Naval Research Laboratory, Code 4671, Washington, DC 203755000; telephone (202) 767-4800; or MRS Headquarters at 9800 McKnight Road, Pittsburgh, PA 15237, telephone (412) 3673003 , $\operatorname{tax}(412) 367-4373$.

\section{MRS BULLETIN - EDITORIAL CALENDER}

April - Materials for Optical Storage

Guest Editors: Matthew Libera, IBM Almaden

Research Center; Richard J. Gambino, IBM T.J. Watson Research Center

May - To Be Announced

June - High Temperature Superconductors

Guest Editor: M. Brian Maple, University of Califormia, San Diego

July - Materials for Vacuum Guest Editor:

Alan Krauss, Argonne National Laboratory

August - Materials Education Guest Editor:

Reza Abbaschian, University of Florida

September - Interfaces, Part I Guest Editors: Dieter Wolf, Argonne National Laboratory; Sidney Yip, MIT

October - Interfaces, Part II Guest Editors: Dieter

Wolf, Argonne National Laboratory; Sidney Yip, MIT

November - Neutron Scattering for Materials

Research Guest Editors: Stephen M. Shapiro,

Brookhaven National Laboratory; Simon C. Moss,

University of Houston

September 4, 1990

December - To Be Announced
April 2, 1990

May 1, 1990

October 4, 1990

November 8, 1990

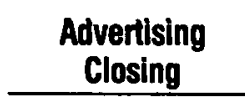

Publication

February 1, 1990

March 5, 1990

April 12, 1990

April 5, 1990

May 10, 1990

June 8, 1990

July 11,1990

August 10, 1990

July 2, 1990

August 6, 1990

September 13, 1990

August 1, 1990

September 6, 1990

October 12, 1990

October 1, 1990

November 6, 1990

December 14, 1990 


\section{VON HIPPEL AWARD of the Materials Research Society \\ Nomination Summary Form}

NAME of CANDIDATE:

TITLE and AFFILIATION (present and recent past):

ADDRESS and TELEPHONE:

EDUCATION:

SUMMARY CTTATION: (Summarize the professional achievements upon which this nomination is based.) (<60 words.)

I. Qualification of Nominees

Nominees for the Materials Research Society's Von Hippel Award must have outstanding scientific credentials, their scientific work must have had a significant impact on materials research, and it must have exemplified an interdisciplinary approach. The scientific discipline of the nominee is of no concern except that the work must have been in areas commonly associated with materials research. The nominee does not need to be a member of the Materials Research Society and nominees of any nationality are eligible. It is not necessary for the nominee to have previously won other major awards. We especially hope to identify individuals who have reached the stage in their careers when they will be first considered for major awards.

II. Nomination Package Requirements

1. A statement by the nominator supporting the candidate's suitability for the Award with respect to:

- interdisciplinary character of the candidate's work

- manner in which the candidate's work spans basic and applied science

- impact of the candidate's work within and outside their immediate professional field.

- Wherever possible, this statement should cite evidence rather than opinion or intuition. Further pertinent information may be added.

2. Supporting information and documents, e.g., lists of the candidate's professional appointments held, honors, awards, patents and publications; the nominator must also provide a separate list of the most important papers and books published by the nominee.

3. Names of three distinguished scientists who have agreed to send letters supporting the nomination with explicit reference to the three criteria of item 1 (above). (Their letters should be sent promptly to the address below.)

4. A list of supporting documents submitted.

A nomination for the Von Hippel Award remains under consideration for three years, so individuals who are nominated in 1990 will remain under consideration through 1992. In preparing nominations, please bear in mind that the nominees for this award should have made outstanding contributions to our profession. Further, since a poorly prepared nomination for an outstanding individual would constitute a disservice to that person, it is important for the nomination package to truly reflect the accomplishments and stature of the nominee.

III. Selection of Von Hippel Award Recipient

The recipient of the Von Hippel Award is determined by a vote of the MRS Council.

IV. Deadline for Submission of Nominations

To be considered for the 1990 Award, the nomination must be submitted by July 1, 1990, to J. Murray Gibson, the MRS Awards Committee, AT\&T Bell Laboratories, Room 1E-234, 600 Mountain Avenue, Murray Hill, NJ 07974. 


\section{Keep Up-To-Date Visit Us at MRS Booth \#416}

Material Concepts in Surface Reactivity and Catalysis

Henry Wise and Jacques Oudar

April 1990 , c. 255 pages, $\$ 65.00$

ISBN: 0-12-759940-1

\section{High-Tech Ceramics}

Viewpoints and Perspectives edited by

Gernot Kostorz

January 1990,256 pages, $\$ 59.50$

ISBN: $0-12-421950-0$

\section{Glass}

Science and Technology

edited by

Donald R. UhImann and

Norbert J. Kreidl

Volume 4A

Structure, Microstructure, and Properties

December 1989,368 pages, $\$ 115.00$

ISBN: 0-12-706704-3

Volume 4B

Advances in Structural Analysis

December 1989,408 pages, $\$ 115.00$

ISBN: 0-12-706707-8

\section{Chemistry at Interfaces}

Finlay MacRitchie

January 1990,283 pages, $\$ 49.95$

ISBN: 0-12-464785-5

\section{Measurement of}

High-Speed Signals in Solid State Devices

\section{edited by}

Robert B. Marcus

March 1990, 456 pages, $\$ 85.00$

ISBN: 0-12-752128-3

\section{Space Groups for}

\section{Solid State Scientists}

Second Edition

G. Burns and A.M. Glazer

March 1990, 360 pages, $\$ 39.95$

ISBN: 0-12-145761-3

\section{Sol-Gel Science}

The Physics and Chemistry

of Sol-Gel Processing

C. Jeffrey Brinker and

George W. Scherer

This is the first book to assimilate the principles of chemistry, physics, and materials science, thereby providing a fundamental understanding of sol-gel processing. Comprehensive in scope, this book follows the sol-gel processing sequence from beginning to end and includes practical "recipes" and applications.

March 1990 , c. 912 pages, $\$ 139.00$ ISBN: 0-12-134970-5

\section{Practical Fourier}

Transform Infrared Spectroscopy

Industrial and Laboratory

Chemical Analysis

edited by

John R. Ferraro and K. Krishnan

December 1989,534 pages, $\$ 69.00$

ISBN: 0-12-254125-1

\section{Ion Beams for}

\section{Materials Analysis}

edited by

J. Roger Bird and James S. Williams

November 1989,450 pages, $\$ 88.00$

ISBN: 0-12-099740-1

Order from your local bookseller or directly from

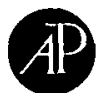

\section{ACADEMIC PRESS}

Harcourt Brace Jovanovich, Publishers Book Marketing Department \#36030

1250 Sixth Avenue, San Diego, CA 92101

CALL TOLL FREE

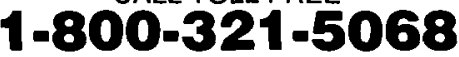

Quote this reference number for free postage and handling on your prepaid order -36030

Prices subject to chrange without notice. O1990 by Academic Press, Inc.
Very High Speed Integrated Circuits edited by

Toshiaki Ikoma

Gallium Arsenide LSI

April 1990, 336 pages, $\$ 75.00$ (tentative) ISBN: 0-12-752 129-1

Heterostructure

May 1990 , c. 324 pages, $\$ 75.00$ (tentative) ISBN: 0-12-752130-5

\section{Solid State Physics}

Advances in Research

and Applications

Volume 43

edited by

Henry Ehrenreich and David Turnbull

January 1990, 344 pages, $\$ 69.50$

ISBN: 0-12-607743-6

\section{Strained Layer}

\section{Superlattices}

Physics

Thomas P. Pearsall

June 1990, c. 272 pages, $\$ 64.50$ (tentative) ISBN: 0-12-752132-1

\section{Strained Layer}

Superlattices

Materials Science

and Technology

Thomas P. Pearsall

July 1990 , c. 432 pages, $\$ 84.50$ (tentative) ISBN: 0-12-752133-X

\section{X-Ray Lasers}

Raymond C. Elton

January 1990,304 pages, $\$ 59.95$

ISBN: 0-12-238080-0

\section{Superconducting Devices} edited by

Steven T. Ruggiero and David A. Rudman March 1990, 416 pages, $\$ 49.95$

ISBN: 0-12-601715-8 


\section{EQUIPMENT EXHIBIT \\ 1990 MRS Spring Meeting \\ San Francisco Marriott \\ Tuesday-Thursday, April 17-19, 1990}

As part of the 1990 Spring Meeting, a major equipment exhibit will display analytical and processing equipment closely paralleling the nature of the technical symposia. The exhibit will be in the San Francisco Marriott, and the technical program has been arranged to allow meeting participants ample opportunity to visit the exhibit.

\section{Academic Press}

Accufiber, Inc.

AET-Addax

Aixtron $\mathrm{GmbH}$

Alcatel Comptech

Anatech Ltd.

APD Cryogenics

Applied Science \& Technology

Astra Scientific

Atom Tech, Inc.

AXIC, Inc.

Bio-Rad Microscience Division

Blake Industries, Inc.

Edmund Buehler $\mathrm{GmbH}$

Cambridge Molecular Design

Catalytica Studies Division

Ceramaseal

Commonwealth Scientific Corp.

CVC Products, Inc.

Denton Vacuum

Elsevier Science Publishing

Emcore

EPI Systems

Charles Evans \& Associates

E.A. Fischione Instruments

Gatan, Inc.

GMW Associates

\section{Show Hours}

Tuesday ..................

Reception.......... 5:00 p.m. - 7:00 p.m.

Wednesday .......... 9:00 a.m. - 5:00 p.m.

Thursday . . . . .

\section{EXHIBITORS \\ (as of February 9, 1990)}

Goodfellow Corporation

Granville-Phillips Co.

Huntington Laboratories

Instruments S.A., Inc.

International Scientific Instruments, Inc.

Ion Tech, Inc.

JEOL U.S.A., Inc.

Keithley Instruments

Kevex Instruments

Lake Shore Cryotronics

Kurt J. Lesker Company

Leybold Inficon/Leybold Vacuum

Luxtron

Materials Science

MDC Vacuum Products Corporation

Microscience, Inc.

MMR Technologies, Inc.

Morris Research

Nano Instruments

National Electrostatics Corporation

NGS/CVT Ltd.

Nor-Cal Products

North Eastern Analytical Corporation

Omicron Associates

Oxford Instruments N.A.

Peabody Scientific
Peak Systems

Ted Pella, Inc.

Perkin-Elmer Corporation

Plasma Sciences

Princeton Gamma-Tech

Princeton Instruments

Princeton Research Instruments

Process Products Corporation

Quantum Design, Inc.

Siemens Analytical X-Ray

South Bay Technology

Spectra Instruments

Stanford Research Systems

Structure Probe, Inc./SPI Supplies

Surface Science Laboratories

Thermionics Laboratory

Tracor Northern

U.S. Bureau of Mines

UHV Instruments

US, Inc.

Vacuum Barrier Corporation

Varian Associates

VCR Group

VG Instruments

Voltaix, Inc.

Wavemat, Inc. 